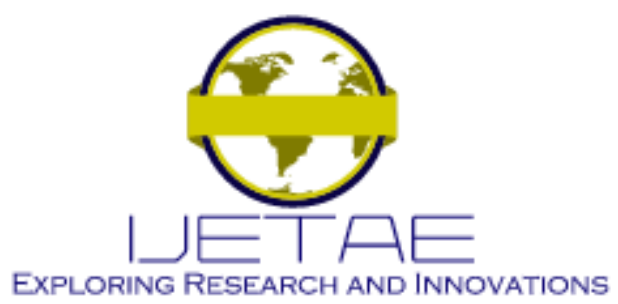

International Journal of Emerging Technology and Advanced Engineering

Website: www.ijetae.com (E-ISSN 2250-2459, Scopus Indexed, ISO 9001:2008 Certified Journal, Volume 11, Issue 10, October 2021)

Manuscript Received: 13 September 2021, Received in Revised form: 10 October 2021, Accepted: 14 October 2021

DOI: $10.46338 /$ ijetae1021_19

\title{
Prototype of New Efficient System to Extremely Reduce Banks Losses
}

\author{
Dr. Omar Khattab ${ }^{1}$, Mariam Bonashi ${ }^{2}$, Shaza Ashraf ${ }^{3}$, Alanoud Almuwaizri ${ }^{4}$ \\ Department of Computer Science and Engineering, Kuwait College of Science and Technology (KCST), Kuwait
}

\begin{abstract}
Due to increasing the number of vehicles loans defaulters, the banks subsequently experience more financial risks. Where each day of delay in paying installments they incur massive losses. Although there are several research works have been conducted in this field, the financial banks' concerns have not been addressed thoroughly. Therefore, in this paper we propose the Improved Vehicular Tracking System (IVTS) in order to provide an optimal solution in terms of efficiency, accuracy and reducing banks losses compared with the research works found in the literature. A prototype system based on the proposed design is successfully implemented and tested using Radio Frequency Identification (RFID) and website application.
\end{abstract}

Keywords - vehicular tracking system (VTS), radio frequency identification (RFID), tracking system (TS).

\section{INTRODUCTION}

The Vehicular Tracking System (VTS) allows tracking and controlling of vehicles all the time via many ways such as online computers, smart phones and tablets [1]. In business, there are many impressive reasons for choosing the VTS [2]:

- Tracking vehicle and employee.

- Recovering vehicle.

- Tracking inventories locations.

- Paying less insurance premiums.

- Enhancing employee safety.

- Saving fuel consumption.

- Monitoring the speed of your vehicle.

- Satisfying customer.

- Enhancing vehicle maintenance.

Radio Frequency Identification (RFID) is a tracking system can be applied in different applications [3-12] to dynamically identify and track the location of objects such as vehicles where a vital data is transferred for operational analysis and planning [4].
Recently, it has been noticed that due to rapid development of economy and population growth the number of vehicles loans is continuously on the increase where it plays a vital role in the bank's sector. However, the banks still incur massive losses as a result of delay in paying installments by loans defaulters. In this paper we therefore propose the Improved Vehicular Tracking System (IVTS) using RFID in order to expedite in recovering the vehicles from the loan defaulters, which in turn extremely reduces banks losses. The IVTS is also more efficient and accurate compared with the recent research works found in the literature.

The rest of the paper is organized as follows: Section II presents related works of the Tracking System (TS). The design of proposed IVTS is presented in Section III. The implementation and testing of the proposed IVTS are presented in Section IV. A discussion is presented in Section V. A conclusion is presented in Section VI. Finally, a future scope is presented in section VII.

\section{RELATED WORKS}

In this paper we have surveyed four recent research works of the TS particularly in the domain of the banks [13-16]. In [13] the authors proposed a VTS by using RFID technology in order to allocate loan defaulters' vehicles by patrolling the city. Once a car is identified, its information is sent for the department of loan defaulters and alerting the police station. In [14] the authors proposed a Secured Parking Spots for Physically Challenged (SPSPC) system by using RFID technology in parking lots for disable people. It identifies vehicles with valid date tag, invalid date tag or even without tag. In [15] an approach was proposed by the authors to protect against unauthorized attack and privacy threats by using RFID systems via tags, back-end servers and GPS. In [16] the author proposed facial recognition in banking sector by using Open $\mathrm{CV}$ and RFID techniques for locker room and cashier cabins to scan and identify both customers and employees. 


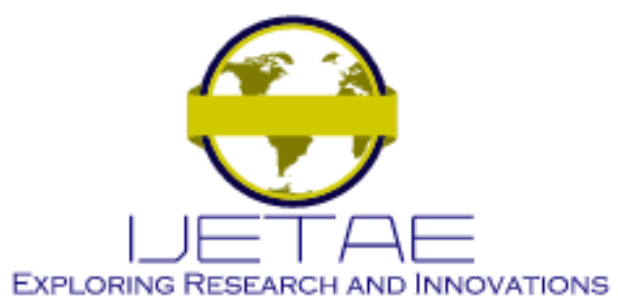

International Journal of Emerging Technology and Advanced Engineering

Website: www.ijetae.com (E-ISSN 2250-2459, Scopus Indexed, ISO 9001:2008 Certified Journal, Volume 11, Issue 10, October 2021)

\section{The Design Of Proposed IVTS}

In the Section II, four recent research works of the TS have been considered [13-16]. We offer a fair comparison between them, in terms of use, technology, consideration and beneficiary. This is shown in Table I. It has been noticed in the Table I that the VTS in [13] is the sole research work which considers the finance as a vital factor for banks, while the works of others are confined in security, privacy and social needs. However, the VTS costs lots in terms of effort, time and money due to patrolling the city in order to allocate the vehicle defaulters. Therefore, we come up with the IVTS to provide a better performance. First, instead of using vehicle fleet to patrol the city in order to allocate the vehicle defaulters, the IVTS allocates them by adding RFID device in each entrance of petrol station which in turn recognize the wanted vehicles efficiently. It obviously leads to extremely reducing banks losses, time and effort due to its perfect place in the petrol station where all vehicles including vehicle defaulters are obliged to regularly fill petrol. Second, instead of using text description for personal information, the IVTS adds defaulters' photos with their vehicles to help the petrol station user to accurately checking whether the driver is the loan defaulters or somebody else.
Table II shows a comprehensive comparison between the IVTS and VTS in terms of similarities and differences.

The IVTS scenario has three main steps as shown in Fig. 1:

- In the bank every purchased vehicle is chipped with RFID tag.

- There is an alarm and undergrounded RFID reader in each entrance of the petrol station. If the vehicle is unwanted it passes safely.

- If the vehicle is wanted, then the RFID reader identifies the vehicle and issues an alarm. The IVTS considers two main users: petrol station user and bank user. This is shown in Fig. 2.

a. The petrol station user checks if the vehicle driver is wanted or not via the civil id, if the driver is unwanted person, he/she is allowed to go and detain the vehicle.

b. Once the petrol station user identifies the wanted vehicle driver, his/her personal information is sent via the IVTS to the bank user to alert the relevant authority in taking the necessary action.

TABLE I

The Fair Comparison of the TS

\begin{tabular}{|c|c|c|c|c|}
\hline Comparison & [13] & [14] & [15] & [16] \\
\hline Use & $\begin{array}{c}\text { Tracking loan } \\
\text { defaulters' vehicles }\end{array}$ & $\begin{array}{c}\text { Identifying the vehicles of } \\
\text { disabled people in parking } \\
\text { lots }\end{array}$ & $\begin{array}{c}\text { Protecting the system } \\
\text { against unauthorized attack } \\
\text { and privacy threats }\end{array}$ & $\begin{array}{c}\text { Facial recognition in } \\
\text { banking sector }\end{array}$ \\
\hline Technology & VTS and RFID & RFID and SPSPC System & $\begin{array}{c}\text { RFID, back-end servers } \\
\text { and GPS }\end{array}$ & RFID and Open CV \\
\hline Consideration & Finance & Social & Security and privacy & Security \\
\hline Beneficiary & Bank & Disabled people & Bank & Customer and employee \\
\hline
\end{tabular}




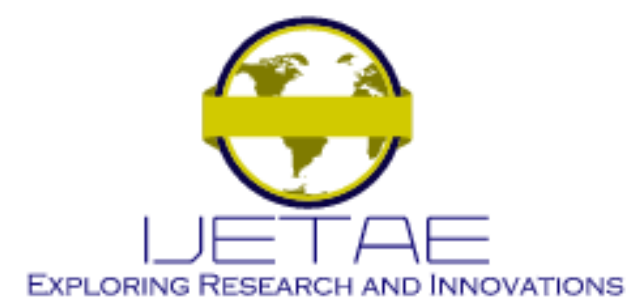

International Journal of Emerging Technology and Advanced Engineering

Website: www.ijetae.com (E-ISSN 2250-2459, Scopus Indexed, ISO 9001:2008 Certified Journal, Volume 11, Issue 10, October 2021)

TABLE II

The Fair Comparison of the VTS vs. IVTS

\begin{tabular}{|c|c|c|c|c|c|c|c|c|c|c|c|}
\hline \multicolumn{2}{|c|}{ Competition } & \multicolumn{5}{|c|}{ The current system (VTS) } & \multicolumn{5}{|c|}{ The proposed system (IVTS) } \\
\hline \multirow{3}{*}{ 尝 } & Use & \multicolumn{5}{|c|}{ Tracking loan defaulters' vehicles } & \multicolumn{5}{|c|}{ Tracking loan defaulters' vehicles } \\
\hline & Consideration & \multicolumn{5}{|c|}{ Finance } & \multicolumn{5}{|c|}{ Finance } \\
\hline & Beneficiary & \multicolumn{5}{|c|}{ Bank } & \multicolumn{5}{|c|}{ Bank } \\
\hline & \multirow[t]{2}{*}{ Difference } & 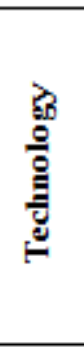 & 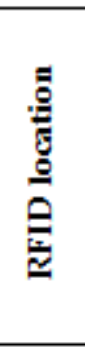 & 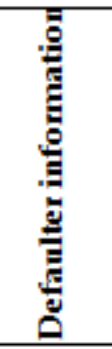 & 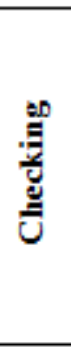 & कु & 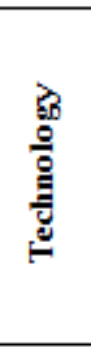 & 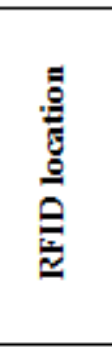 & 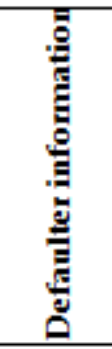 & 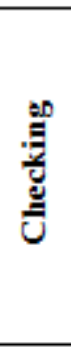 & कु \\
\hline & & VTS & $\begin{array}{l}\text { Car } \\
\text { fleet }\end{array}$ & Texted & No & High & IVTS & $\begin{array}{l}\text { Petrol } \\
\text { station }\end{array}$ & $\begin{array}{c}\text { Texted } \\
\& \\
\text { photo }\end{array}$ & Yes & $\begin{array}{l}\text { Extremely } \\
\text { reduced }\end{array}$ \\
\hline
\end{tabular}




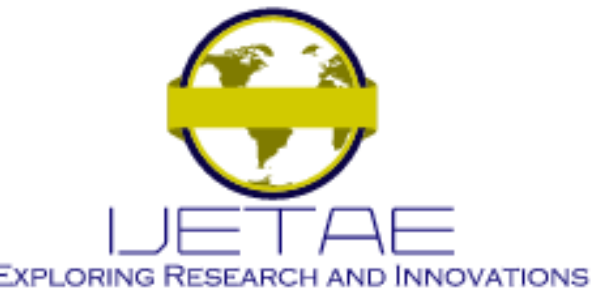

International Journal of Emerging Technology and Advanced Engineering

Website: www.ijetae.com (E-ISSN 2250-2459, Scopus Indexed, ISO 9001:2008 Certified Journal, Volume 11, Issue 10, October 2021)

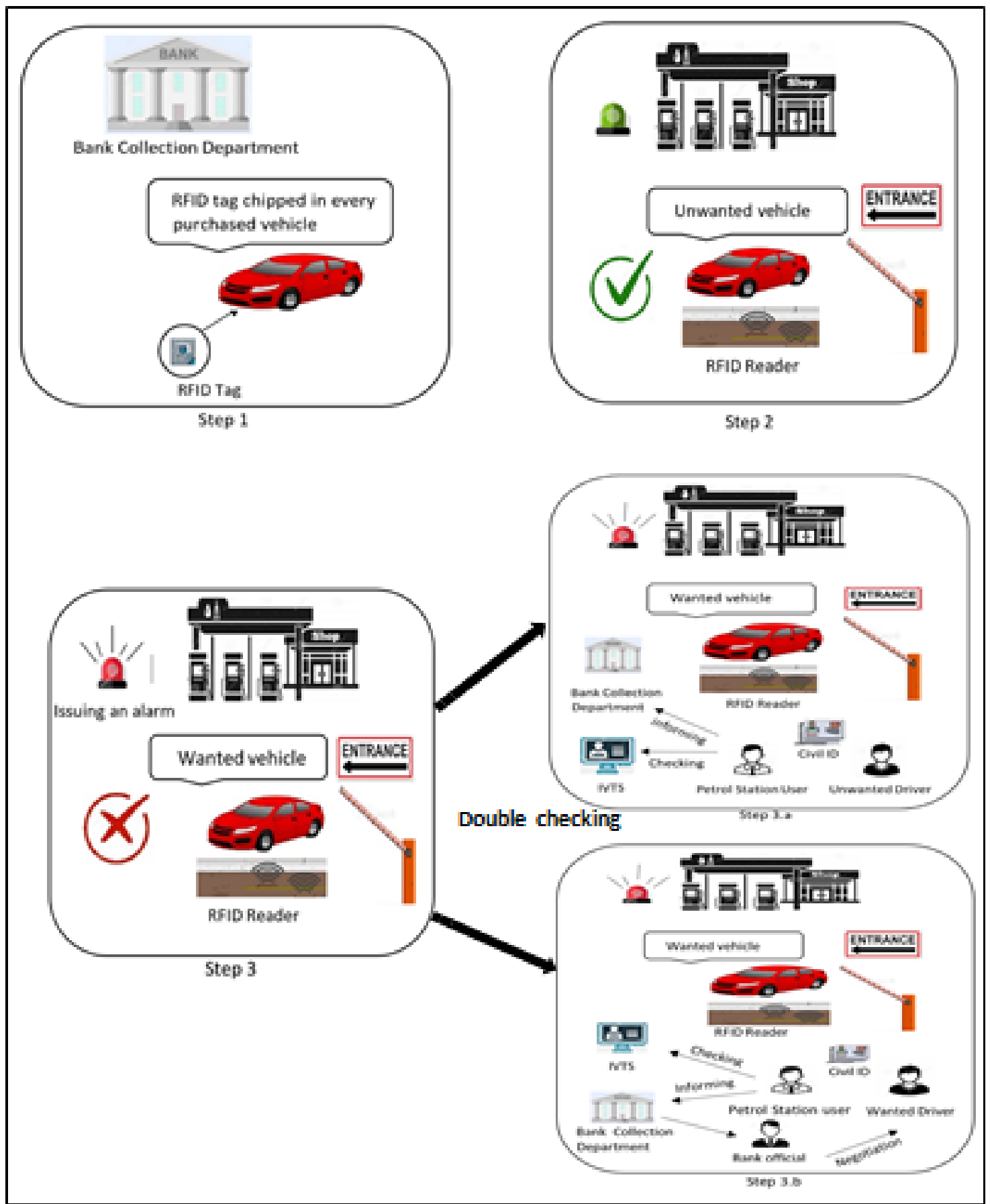

Figure 1. The IVTS Scenario 


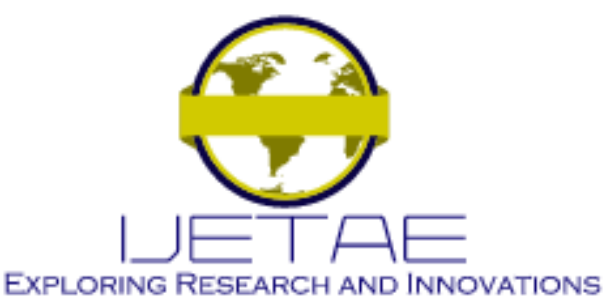

International Journal of Emerging Technology and Advanced Engineering

Website: www.ijetae.com (E-ISSN 2250-2459, Scopus Indexed, ISO 9001:2008 Certified Journal, Volume 11, Issue 10, October 2021)

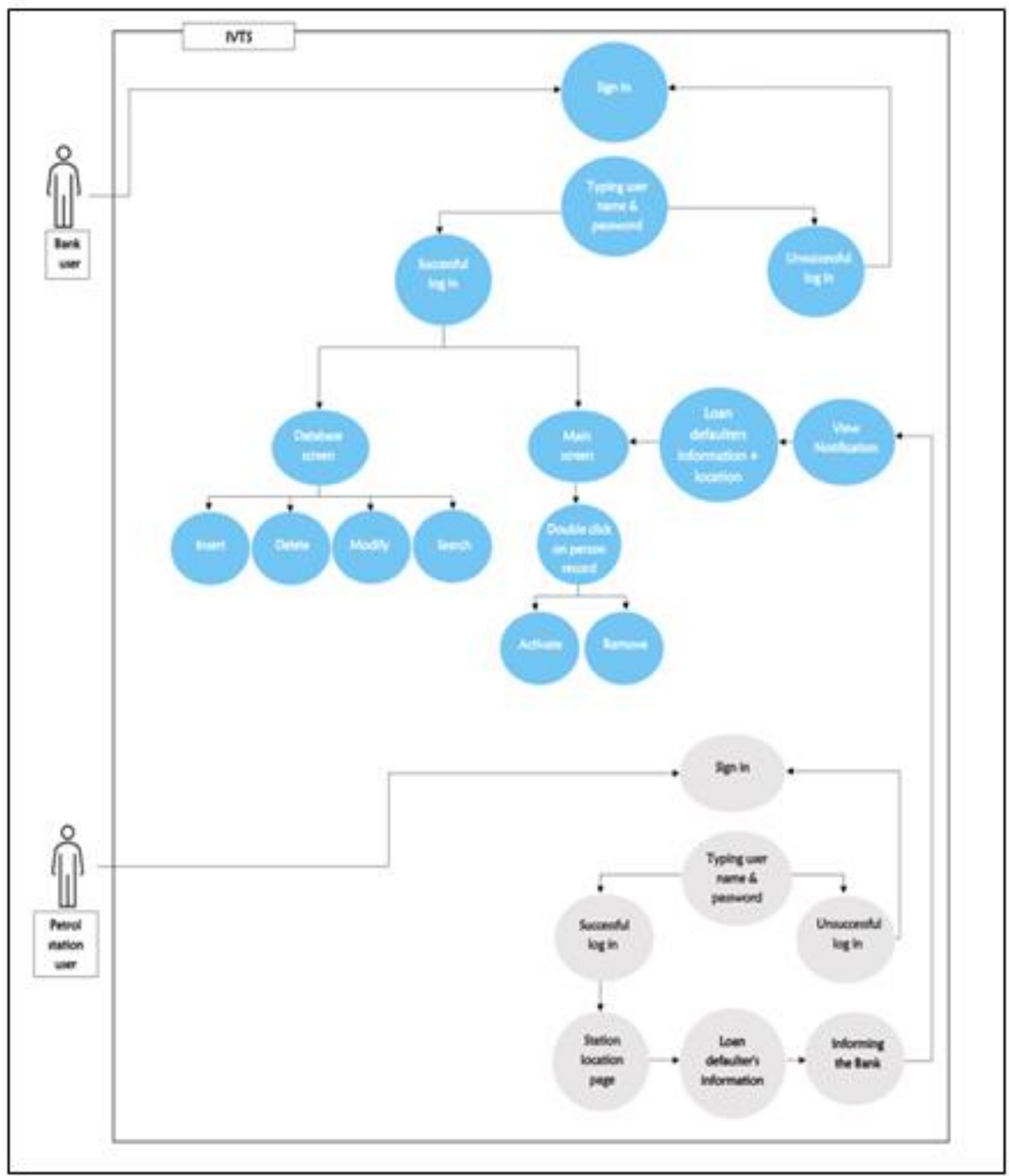

Figure 2. The IVTS Flowchart 


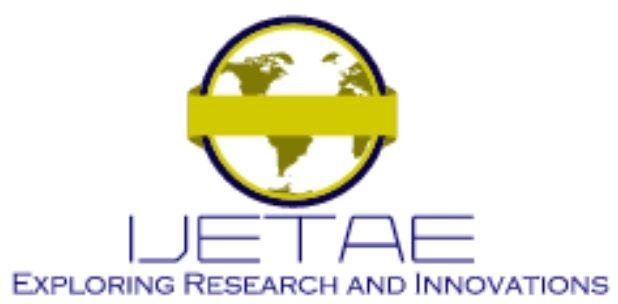

International Journal of Emerging Technology and Advanced Engineering

Website: www.ijetae.com (E-ISSN 2250-2459, Scopus Indexed, ISO 9001:2008 Certified Journal, Volume 11, Issue 10, October 2021)

\section{The IMPLEMENTATION AND Testing OF THE PROPOSED IVTS}

A prototype of IVTS has been successfully implemented and tested for different scenarios: petrol station user and bank user. List and description of the used hardware and software are shown in Fig. 3 - Fig. 9.

Red and green LEDs are used in order to notify the petrol station user if the vehicle is wanted or not. In case the vehicle is wanted, the red LED lights otherwise the green is taken place. Specifications: $10 \mathrm{~mm}$ red and green LEDs. This is shown in Fig. 3.

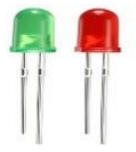

Figure 3. Red and Green LEDs

RFID reader is able to read the RFID tag of the vehicle once it enters the petrol station. Specifications: read and write to RFID tags up to $6 \mathrm{~cm}$ away. Supports EM4100 series, ISO11785 FDX-B and our own Phidget tag protocols. This is shown in Fig. 4.

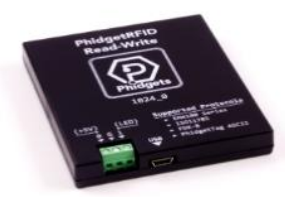

Figure 4. RFID Reader

RFID tag is chipped in every purchased vehicle from the bank collection department. Every vehicle has a unique tag ID that helps in recognizing the wanted vehicle. Specifications: a credit card sized EM4102 RFID tag. This is shown in Fig. 5.

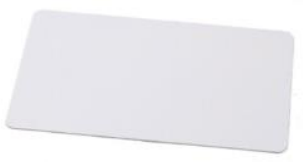

Figure 5. RFID Tag

USB cable is connected with the RFID reader and the laptop. Specifications: mini-USB cable $180 \mathrm{~cm} 24 \mathrm{AWG}$. This is shown in Fig. 6.

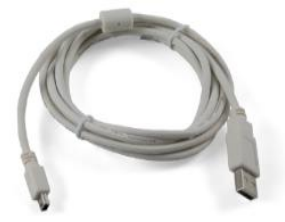

Figure 6. USB Cable

Laptop is used for creating the whole database and building system. Specifications: DELL Laptop, Windows 10, core 15 processor, 8 GB RAM. This is shown in Fig. 7.

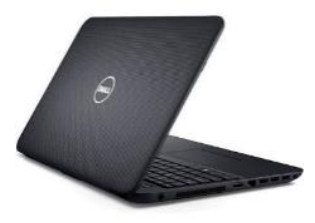

Figure 7. USB Cable

The Phidget control panel is a powerful tool that helps in developing Phidgets applications. With the Phidget control panel, all Phidgets that are attached to the machine or a remote machine can be seen. Therefore, it is used for testing the components such as RFID reader and LEDs, etc. This is shown in Fig. 8.

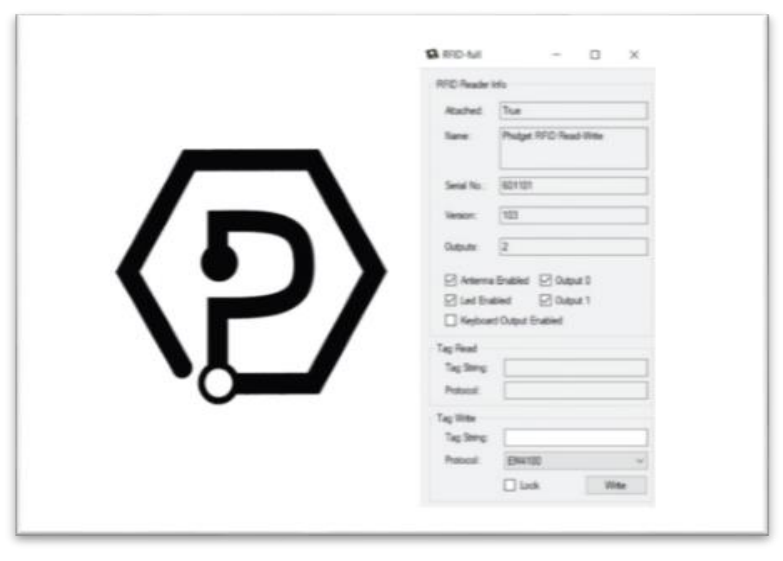

Figure 8. USB Phidget Control Panel

Microsoft Visual basic is used to build and design the IVTS. It is also used to connect the hardware components with software by uploading and using the Phidget library. This is shown in Fig. 9. 


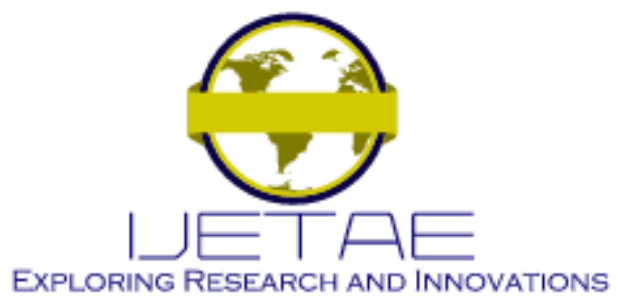

International Journal of Emerging Technology and Advanced Engineering

Website: www.ijetae.com (E-ISSN 2250-2459, Scopus Indexed, ISO 9001:2008 Certified Journal, Volume 11, Issue 10, October 2021)

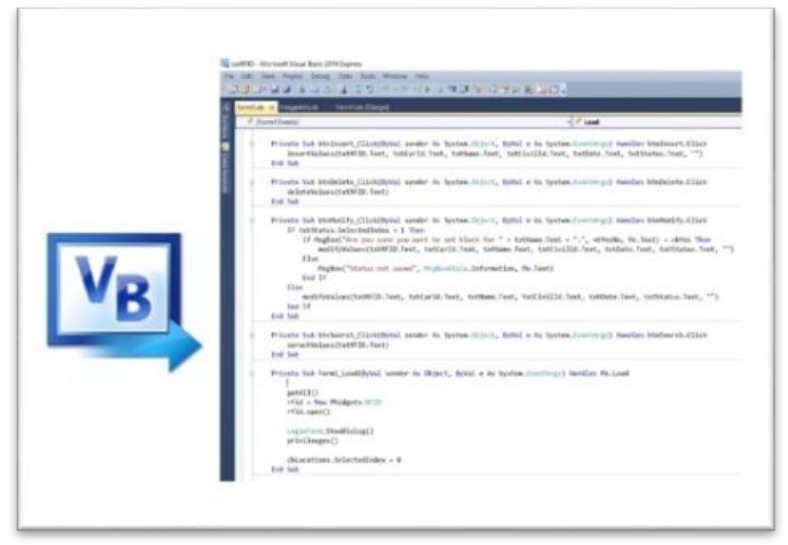

Figure 9. Microsoft Visual Basic

First, we started by testing the hardware components (LEDs, RFID tag and RFID reader) to ensure their effectiveness. This was done by using Phidget control panel application. Second, we uploaded the Phidget library to visual basic in order to use it and make the connection between hardware components and software. Once the connection was done, we started seeking a website where we could reserve a domain name and host through it.
We used (GoDaddy website) in order to achieve this procedure. After reserving the domain and the host, we received a username and password to cPanel to be able to simplify the process of hosting the website. By using it we had the ability to create the database and upload the php files to it. The following steps show the tools that we used in cPanel.

1. MySQL Databases: This option is used to create the database, create username and password and manage user privileges.

2. PhpMyAdmin: This option is used to create the database fields.

3. File manager: This option is used for uploading the php files to the server. Each php file contains a function that could be used as link between software and the server such as modify, insert, delete and search functions.

Then, we started to design and program the IVTS interface.

\section{A. Petrol Station User}

This step has two scenarios, one is for unwanted vehicle (Fig. 10) and the other for wanted vehicle (Fig. 11). 


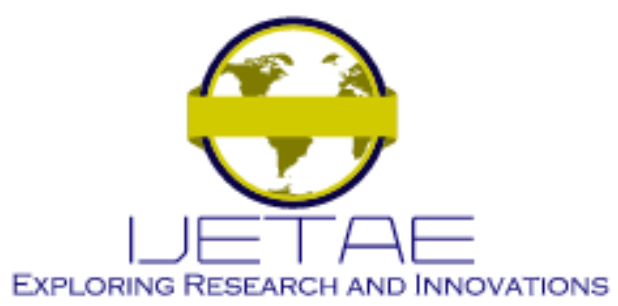

International Journal of Emerging Technology and Advanced Engineering

Website: www.ijetae.com (E-ISSN 2250-2459, Scopus Indexed, ISO 9001:2008 Certified Journal, Volume 11, Issue 10, October 2021)

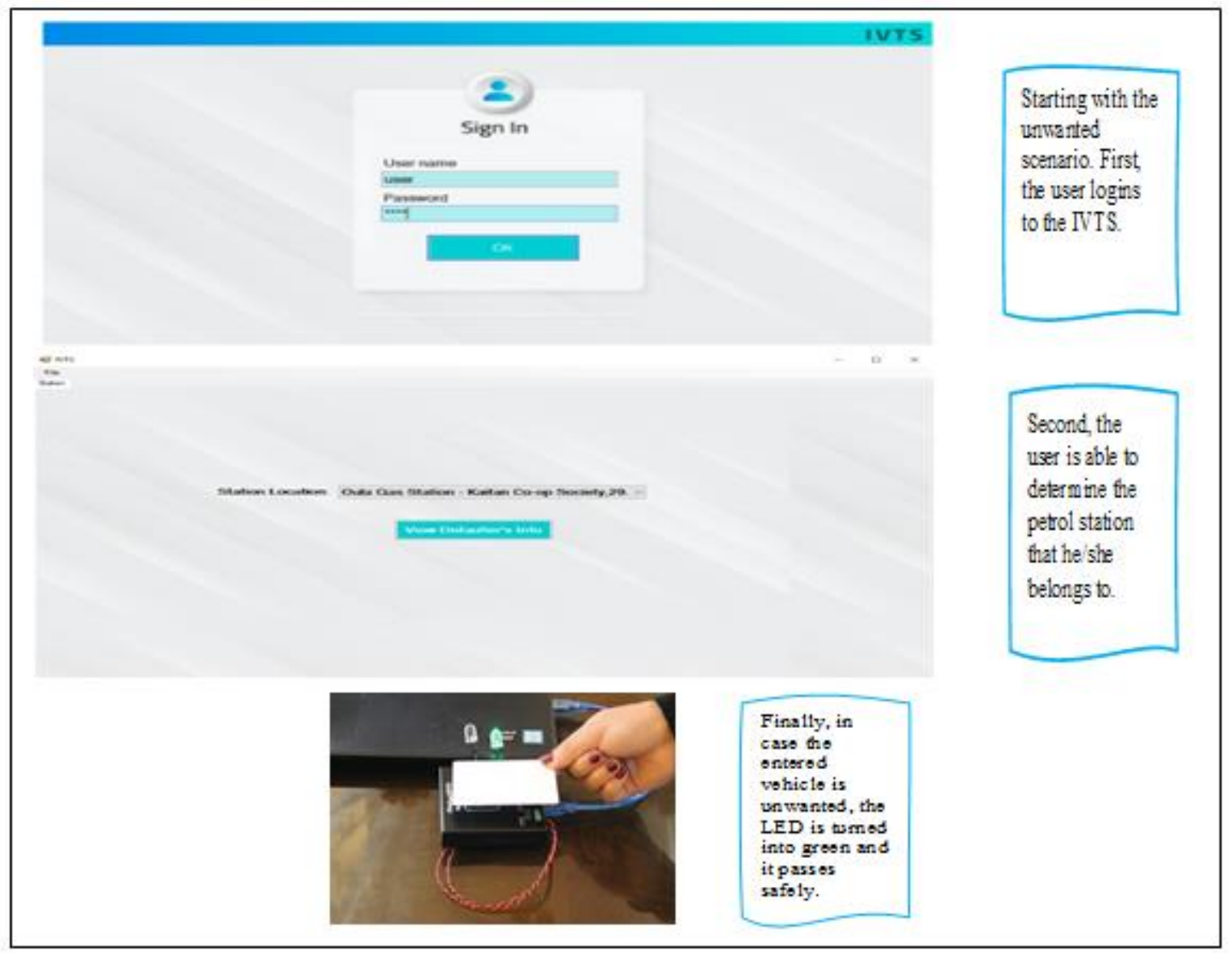

Figure 10. Unwanted Vehicle Scenario 


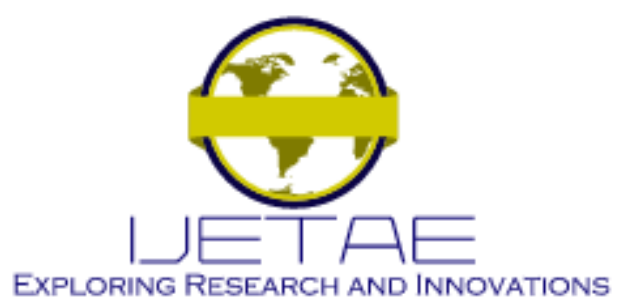

International Journal of Emerging Technology and Advanced Engineering

Website: www.ijetae.com (E-ISSN 2250-2459, Scopus Indexed, ISO 9001:2008 Certified Journal, Volume 11, Issue 10, October 2021)

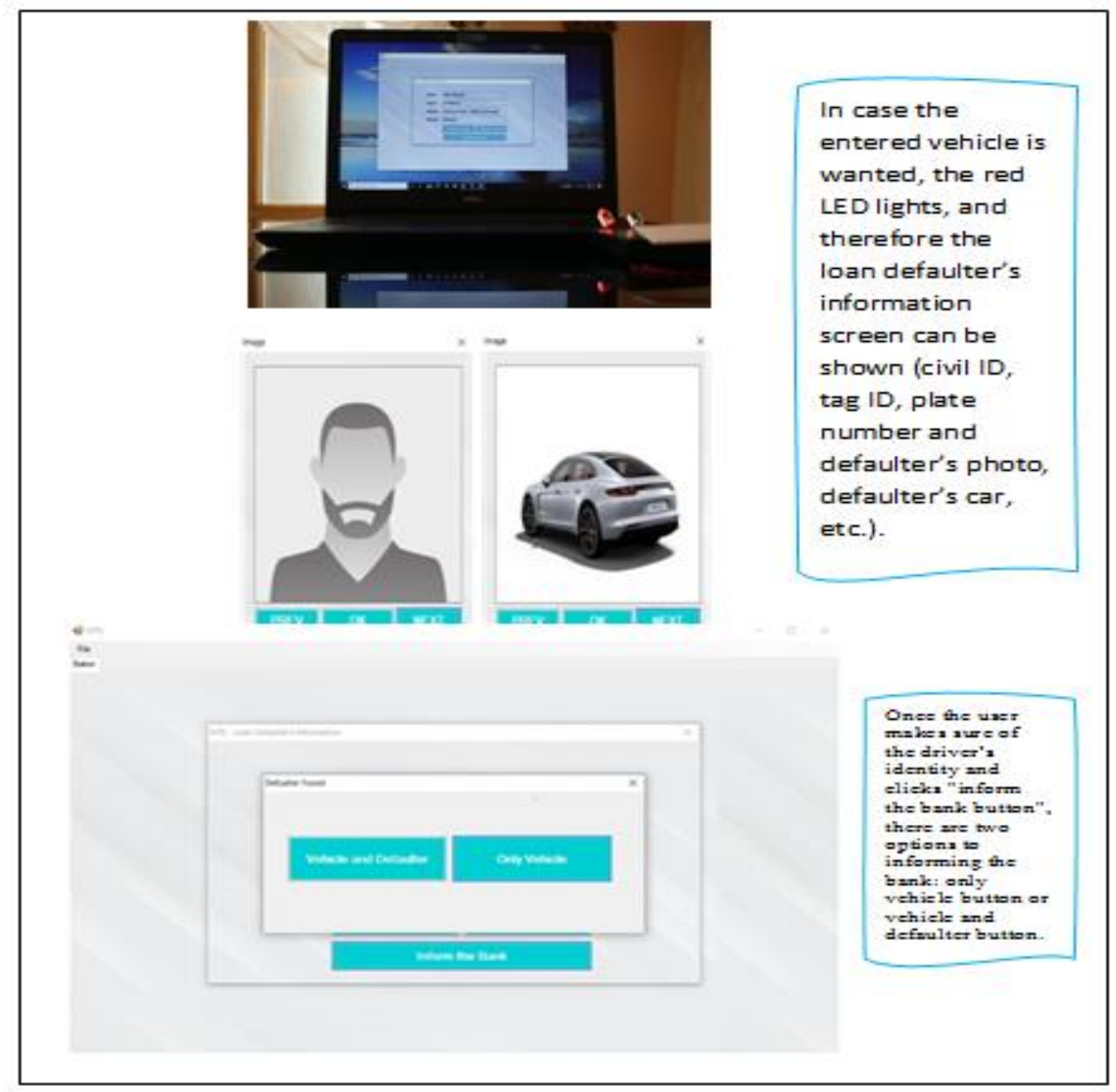

Figure 11. Wanted Vehicle Scenario

\section{B. Bank User}

\section{Scenario 1}

This scenario focuses on generating database as shown in Fig. 12. This is the most important screen because all the next functions of the IVTS are reliant on it. By using it, the bank user has the privileges to insert, delete, modify and search in the database for every person who wants to buy a new vehicle from the bank. The information that could be entered to the fields are RFID tag, plate number, name, civil ID, date, vehicle, person's photo, status (normal/blacklist), phone number and email.

\section{Scenario 2}

In this scenario, the bank user is able to activate or deactivate (remove) the chip as shown in Fig. 13.

\section{Scenario 3}

As it is shown in Fig. 14, there are four steps in case of wanted vehicle or defaulter has been found.

1. The bank user logins by entering the username and password.

2. Bank user is notified immediately in three ways via: message box, SMS text and email.

3. There is a loan defaulter's information message box received to the bank user, including the vehicle and defaulter's photo. Also, the petrol station map button.

4. Once the bank user presses on the map button, the recent petrol station location is shown. 


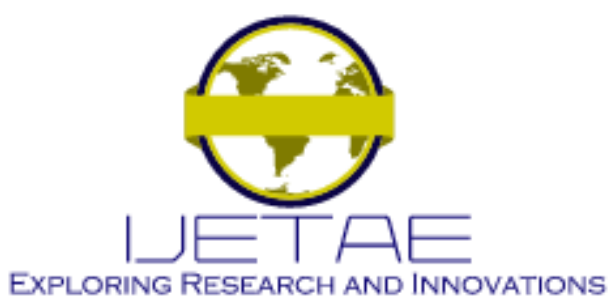

International Journal of Emerging Technology and Advanced Engineering

Website: www.ijetae.com (E-ISSN 2250-2459, Scopus Indexed, ISO 9001:2008 Certified Journal, Volume 11, Issue 10, October 2021)

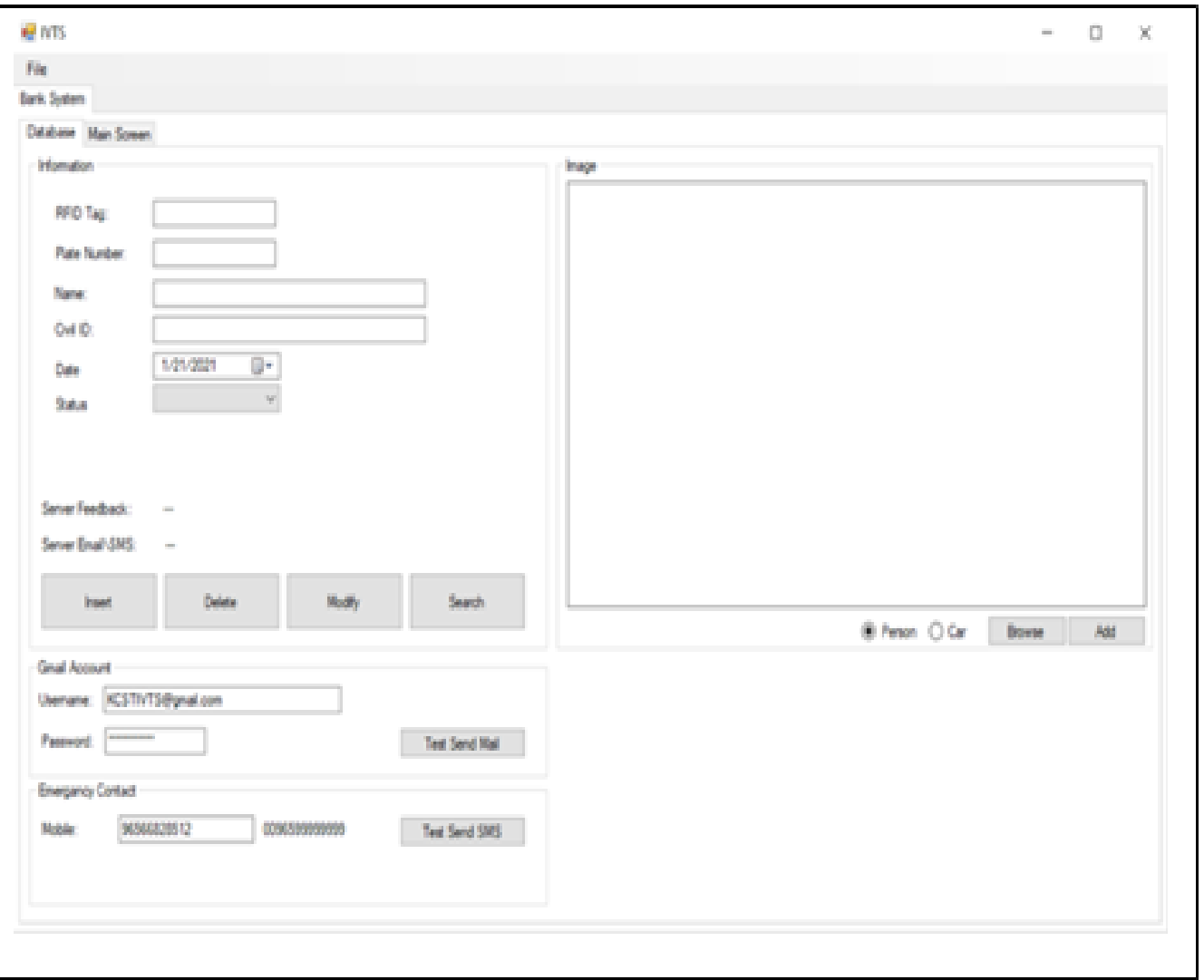

Figure 12. IVTS Main Screen 


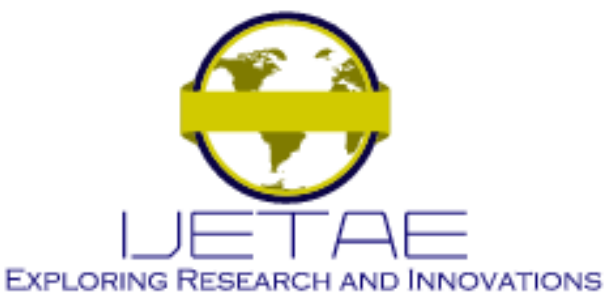

International Journal of Emerging Technology and Advanced Engineering

Website: www.ijetae.com (E-ISSN 2250-2459, Scopus Indexed, ISO 9001:2008 Certified Journal, Volume 11, Issue 10, October 2021)

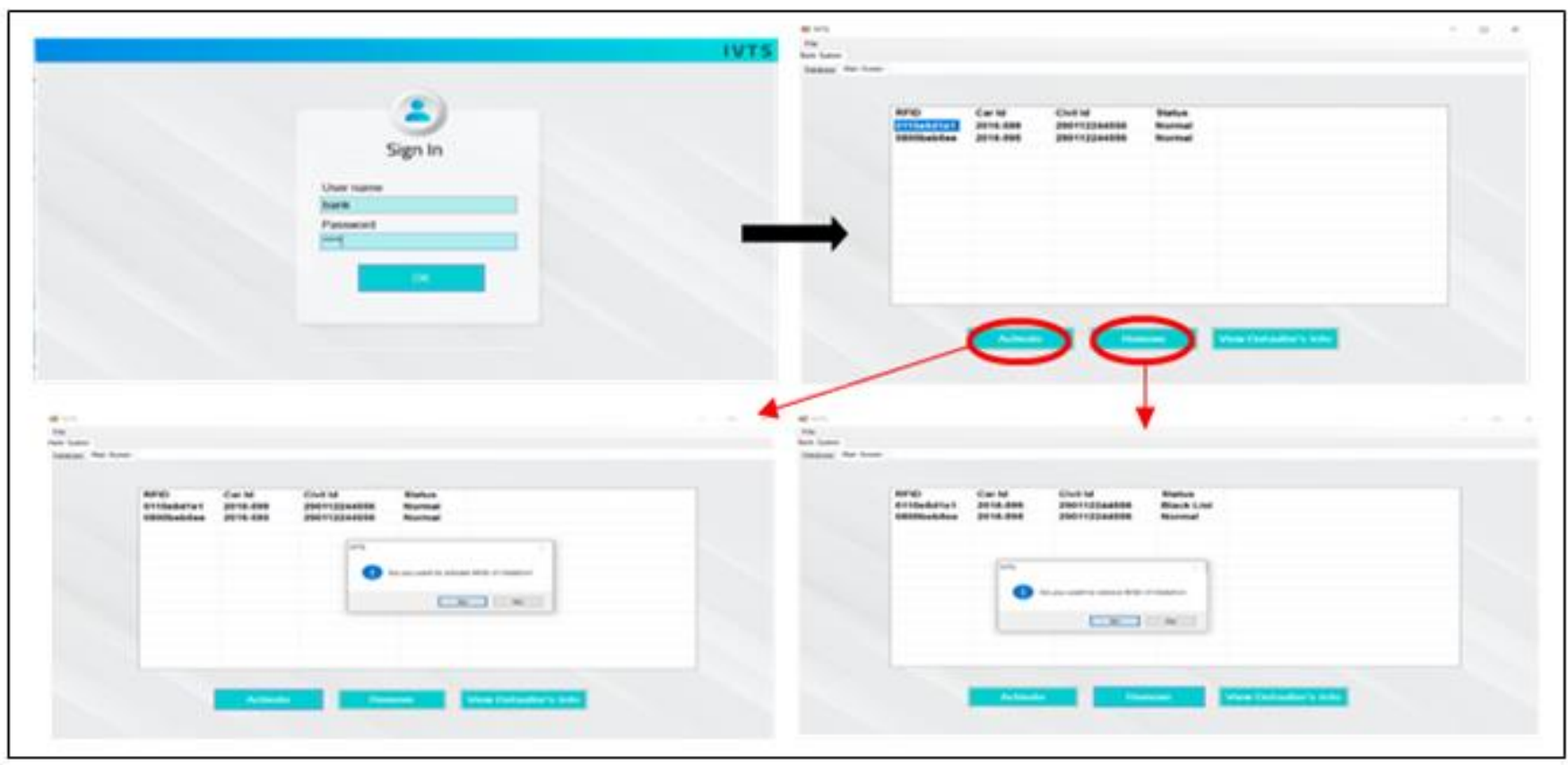

Figure 13. Activation and Deactivation Chip
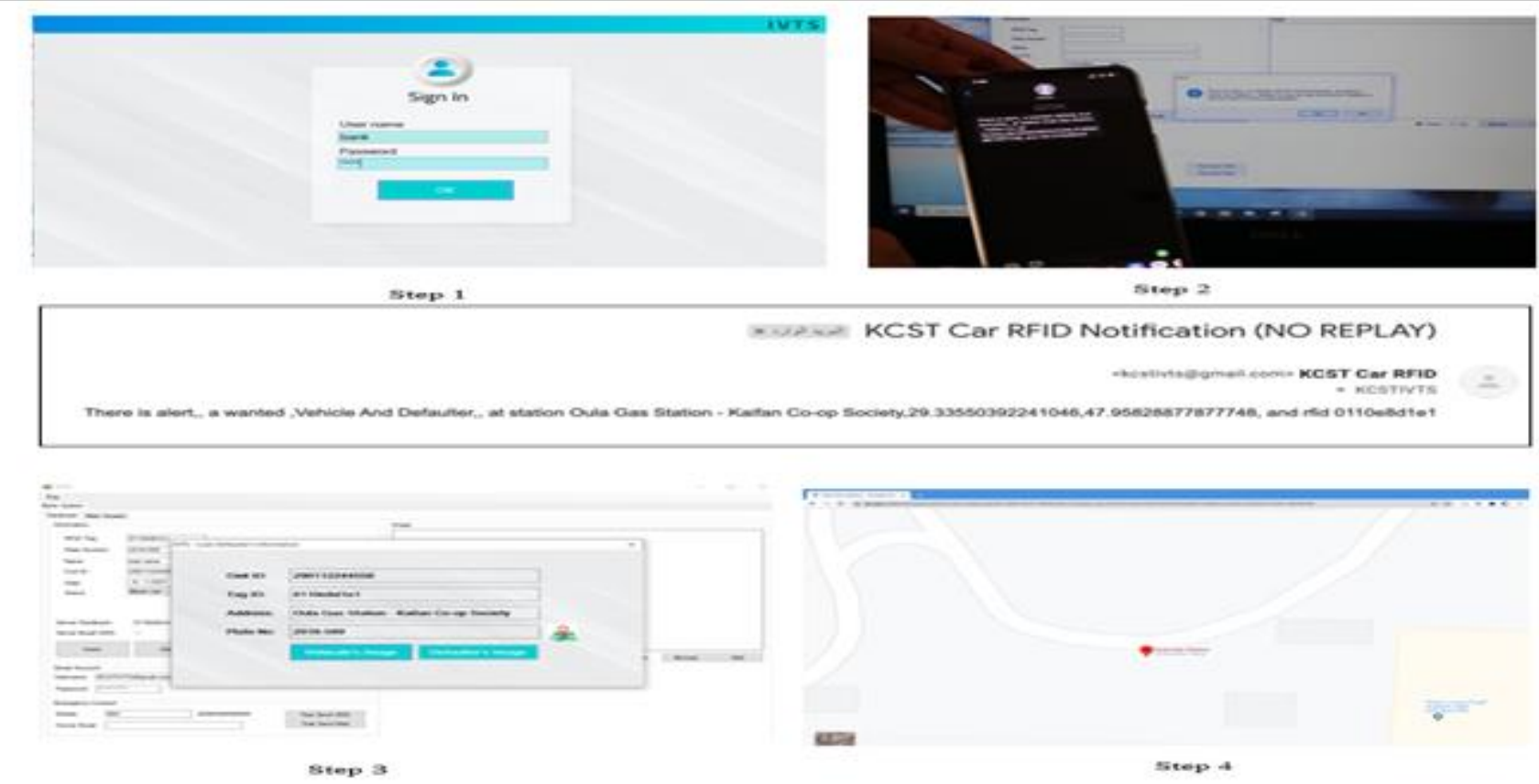

Figure 14. Wanted Vehicle or Defaulter 


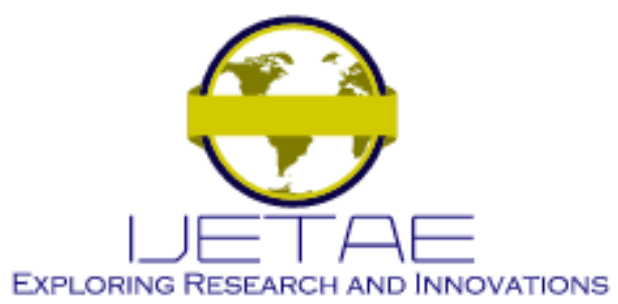

International Journal of Emerging Technology and Advanced Engineering

Website: www.ijetae.com (E-ISSN 2250-2459, Scopus Indexed, ISO 9001:2008 Certified Journal, Volume 11, Issue 10, October 2021)

\section{DISCUSSION}

The goal of the IVTS is to be executed fully functioning in terms of hardware and software. We have fulfilled these conditions through implementing and testing the prototype of the IVTS, which have proved effectiveness of the selected software and hardware components. Regarding to interfacing of the hardware and software, first of all Phidget application has been installed in order to test the components of RFID reader and LEDs. After that, we have been able to connect hardware with the software through the use of Phidget library in Visual Basic. For database and IVTS connection, we used GoDaddy website to reserve a domain and host in order to store and create our database. Then, we created php functions to be able to bond our database with the Visual Basic.

This obviously helps the banks in efficiently recapturing loan defaulters' vehicles and reducing banks losses compared with the recent research work, which incur noticeable cost in terms of effort, time and money due to patrolling the city in order to allocate the vehicle defaulters.

It has been tested that the IVTS has accurately functioned in viewing defaulters' information such as vehicle and defaulters' photos, civil ID, plate number, phone number, etc. This has been applied by the petrol station user through choosing "the vehicle only" or " vehicle and defaulter". Moreover, the petrol station user informs the concerned bank by sending SMS text and email in order to take the necessary action. A prototype of IVTS is shown in Fig. 15.

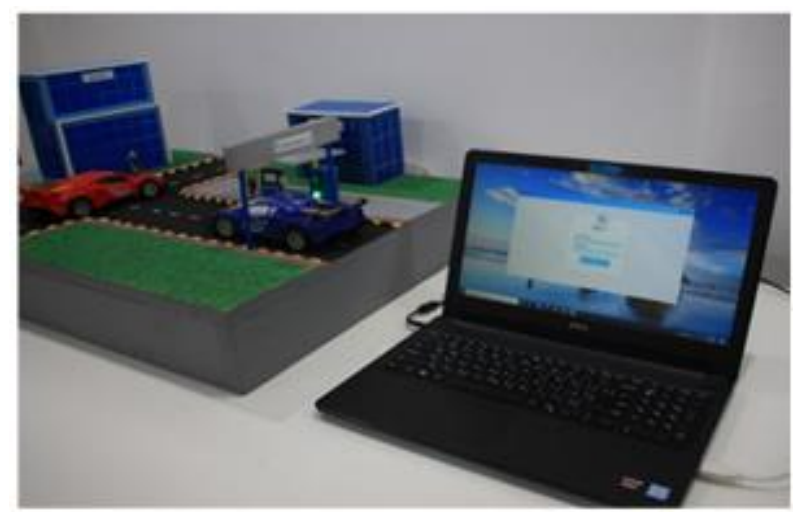

Figure 15. IVTS Prototype

\section{CONCLUSION}

In this paper we considered the finance as a vital factor for banking sector where it was not considered thoroughly in the literature. We therefore successfully designed, implemented and tested a prototype of the IVTS which proved its efficiency and accuracy in reducing banks losses compared with the previous work found in the literature: a) viewing defaulters' information such as vehicle and defaulters' photos, civil ID, plate number, phone number, etc. b) the petrol station user informs the concerned bank by sending SMS text and email in order to take the necessary action which result in recapturing loan defaulters' vehicles and reducing banks losses.

\section{FUTURE SCOPE}

The IVTS could be developed to be a comprehensive solution in providing more services for banking sector taking into account safety and security.

\section{REFERENCES}

[1] What is Vehicle Tracking System?. Arvento Mobile Tracking and Fleet Management Systems. Available online: https://www.arvento.com/en/what-is-a-vehicle-tracking-system, Accessed on 18 Aug, 2021.

[2] Why Vehicle Tracking Is Important For Your Business. Available online: Telematics.com. https://www.telematics.com/vehicletracking-important-business/, Accessed on 18 Aug, 2021.

[3] O. Khattab, H. Matbaqi, H. Dashti and R. Abdullah, A Market Research Study on a Peer-to-Peer Network, International Journal of Advanced Trends in Computer Science and Engineering, vol. 9, (2020), 87-90.

[4] O. Khattab, A. Almetlaqem, D. Almutairi, M. Alnaser and M. Almutairi, Prototype of New Reliable Airport Luggage Tracker System, International Journal of Emerging Technology and Advanced Engineering, 11(8) (2021), 42-47.

[5] F. P. R. Rouniyar, S. P. Saxena and T. A. K. Sahoo, SSAS: RFIDBASED Smart Shopping Automation System, International Conference on Communication and Signal Processing (ICCSP), (2020), 1016-1020.

[6] W. Sun, Destructive and Constructive Full Duplex Relaying for Commodity RFID System, in IEEE Journal of Radio Frequency Identification, (2021), 1-10.

[7] W. Sun and K. Srinivasan, Allergie: Relative Vehicular Localization with Commodity RFID System, IEEE International Conference on RFID (RFID), (2020), 1-8.

[8] W. Sun, Destructive Full Duplex Relay for Commodity RFID System, IEEE International Conference on RFID (RFID), (2020), $1-8$. 


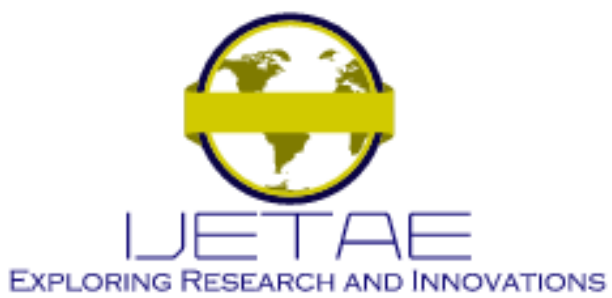

International Journal of Emerging Technology and Advanced Engineering

Website: www.ijetae.com (E-ISSN 2250-2459, Scopus Indexed, ISO 9001:2008 Certified Journal, Volume 11, Issue 10, October 2021)

[9] L. D. Rodić, T. Perković, P. Šolić, M. Škiljo and Z. Blažević, RFID Performance Evaluation in a Retail Store, 5th International Conference on Smart and Sustainable Technologies (SpliTech), (2020), 1-3.

[10] T. Zhang, C. Cao, H. Yu and Y. Liu, Design and Implementation of Dairy Food Tracking System Based on RFID, International Wireless Communications and Mobile Computing (IWCMC), (2020), 21992203.

[11] Z. Chen, P. Yang, J. Xiong, Y. Feng and X. -Y. Li, TagRay: Contactless Sensing and Tracking of Mobile Objects using COTS RFID Devices, IEEE INFOCOM - IEEE Conference on Computer Communications, (2020), 307-316.

[12] S. Joshi and A. Dwivedi, RFID SYSTEM-Used for Monitoring and Tracking Patient (MTP), International Conference on Computer Science, Engineering and Applications (ICCSEA), (2020), 1-10.
[13] S. Miniaoui, K.F. Bin Hashim and S. Atalla, Vehicle Tracking System: Availing RFID Business Value in Reducing Banks' Loss From Vehicle Loans, 2nd International Conference on Communication Engineering and Technology (ICCET), Nagoya, Japan, (2020), 117-120.

[14] S. Miniaoui, S. Sukic and N. Doğru, An Innovative RFID-Based Solution to Secure Parking Spots for Physically Challenged, TEM JOURNAL, vol. 5, (2016), 133-142.

[15] D. Ma, N. Saxena, T. Xiang and Y. Zhu, Location-Aware and Safer Cards: Enhancing RFID Security and Privacy via Location Sensing, IEEE Transactions on Dependable and Secure Computing, vol. 10, (2013), 57-69.

[16] K. Neeraja, P.R. Chandra Rao, S. Maloji and M. Hussain, Implementation of Security System for Bank Using Open CV and RFID, International Journal of Engineering and Technology, vol. 7, (2018), 187-192. 